Article

\title{
Digital Entrepreneurship in Finance: Fintechs and Funding Decision Criteria
}

\author{
Kristin Hommel and Peter M. Bican *(D) \\ Chair of Technology Management, University of Erlangen-Nuremberg, 90762 Fürth, Germany; \\ kristin.h1@icloud.com \\ * Correspondence: peter.bican@fau.de
}

Received: 24 August 2020; Accepted: 27 September 2020; Published: 29 September 2020

check for updates

\begin{abstract}
After the 2007-08 global financial crisis, research flourished on entrepreneurship through digital innovation in the financial market as well as on investors' influence on digital technology-based entrepreneurs' funding decisions. This study combines these two research streams to analyze the decision-making criteria for funding financial technology companies (fintechs), hybrid companies that combine digital entrepreneurship, technology, and banking. The study first uses prior literature to derive important characteristics to define fintechs and then uses 12 expert interviews to elaborate on decision-making criteria in funding. Except for smaller peculiarities, fintech funding does not appear to differ from that of other digital entrepreneurship in different markets, and-as with most digital business models—scalability was identified as a key criterion. Additionally, by serving as a major provider of money for young companies, banks have changed their role and positioning in funding new financial technology entrepreneurs. Through developments in digital technology, banks have shifted from traditional money-lending activities (i.e., debt-financing) to becoming stakeholders in fintechs and, hence, equity investors. We also describe how these formerly distinct fields have converged due to regulatory requirements, digital newcomers, and a need for constant innovation, with their future sustainable development dependent on sharing and collaboration.
\end{abstract}

Keywords: digital entrepreneurship; fintech; funding; decision criteria; success factors; startups; venture capital; investors

\section{Introduction}

In the previous decade, traditional banks have struggled to maintain their market and have faced competition from an increasing number of financial start-ups-an issue of the greatest interest to investors [1]. These financial technology companies (fintechs) are gaining momentum, fueled by drivers such as the sharing economy [2,3], and include peer-to-peer lending platforms that have opened marketplaces for multiple economic actors and enabled the co-creation of value as Uber has for cars [4,5]. Between 1990 and 2008, 450 venture capital deals occurred in financial services, thus ranked among the 10 most important industries [6]. After the 2007-08 global financial crisis, however, fintechs started to apply new technologies in the financial market and have changed the way of doing business in all sectors of finance [7]-a development that is still ongoing. Fintech investments doubled from 2017 to 2018, with approximately US\$112 billion invested globally in 2018, and the amount invested in Europe tripling during the same period [1].

Mainly driven by cost and risk expectations, investors strive to minimize the principal-agent problem [8] and overcome information asymmetries between entrepreneurs and investors [9], meaning that providing investors with sufficient information is a prerequisite, as are additionally influencing criteria (e.g., [10]). Although fintechs are gaining increasing attention from all types of investors, the current literature predominantly focuses on start-ups in general and not specifically on 
the digital economy with its rapidly changing financial environment. To address this research gap, this paper (1) identifies criteria for investors' decision-making and (2) analyzes these criteria in the context of the financial technology industry to answer the research question:

Which components attract investors most when they are deciding whether to invest in a fintech company?

Thereby, we contribute to the existing literature by using insights from investors and startups to highlight new aspects of decision-making criteria for funding and fintechs, demonstrating how funding stage and investor type induce the application of different investment criteria and that decision-making criteria should not be assessed in isolation. Additionally, we identify the interdependency and changing role of banks as fintechs' investors, partners, and competitors; unlike other startups, fintechs are not solely investment objects for banks.

We recommend collaboration and trust-based relationships to mutually benefit fintechs and established banks. In this regard, and contrary to most other industries, fintechs must be operated by experienced founders with a clear vision since investors expect founders to run the business successfully from Day 1. To stay competitive, especially internationally, digitization and technologies should be promoted both by governmental institutions and companies themselves. With scalability as one of the key criteria identified, fintechs should maintain their ability to implement new processes in an agile, rapid way to succeed beyond their domestic markets [11].

Based on the results of the theoretical review, we developed an interview guide covering the most important factors for funding decisions from current research. The insights from the literature were challenged through semi-structured interviews with 12 industry experts, including founders, investors, and advisors. We then used qualitative content analysis [12] to analyze these experts' main statements and answered the research question using both the literature and the empirical findings. This paper first describes the results from the literature review and the interview methodology before discussing the empirical results, limitations, and finally suggested directions for future research.

\section{Selected Literature Review}

\subsection{Fintechs and the Traditional Banking Market}

Fintechs are the focus of increasing investment and interest, with a KPMG study on the fintech market finding the value of global deals in the first half of 2018 had already exceeded the total amount for 2017 [1]. New regulations like the German Second Payment Services Directive (PSD2) and the European General Data Protection Regulation (GDPR) have boosted fintech development [1], and the costs of implementing new regulations have provided the foundation for disruptive technologies that provide more efficient and compliant systems [13]. Following the definition of Arner et al. [7], this study examines the "Fintech 3.0" phenomenon that began after the 2007-08 global financial crisis $[7,14]$. The largest fintech market developed in the United States, followed by the United Kingdom (the largest, most relevant fintech market in Europe) [15]. Since fintechs in Europe and the United States began to evolve after the global financial crisis, their characteristics and backgrounds differ from Asian fintechs, which in particular offer solutions for lack of existing banking infrastructures [7].

According to Haddad and Hornuf [15], fintechs can be established more easily in well-developed economies, where the infrastructure and market regulations already exist; this infrastructure, plus affordable technology, is critical to creating financial innovation that is sustainable and unique [16]. Haddad and Hornuf [15] also argue that fintech formation takes place more often in economies in which access to loans is more difficult. Following this argumentation, scalability plays a key role in new financial start-ups and fintechs' profits remain quite small until a scalable number of customers has been convinced. This scalability of processes can be achieved by platform creation, which leads to economies of scale and, hence, reduced costs and user networks being built-a key concept applied in the sharing economy [17]. Additionally, Ozili [18] notes that financial inclusion can positively affect the economy in terms of poverty reduction and economic growth, and innovations in digital finance can positively influence banks' performance and profitability. Fintechs' key advantages are greater 
control of customers' personal finance, rapid financial decision-making, and the ability to make and receive payments within seconds $[18,19]$, although this results in a "trade-off between efficiency and [data] security" [18].

In terms of the economy's effect on fintech development, Claessens et al. [20] found the country's GDP and a less competitive banking system boost fintech activity, especially in the field of credit. From a regulatory perspective, the greatest challenges are then to ensure both consumer and investor protection and to guarantee financial stability. Claessens et al. [20] also analyzed fintechs to address the principal-agent problem (e.g., in crowdfunding or lending in general) by offering real-time data via platforms, with the platform "act[ing] as an agent for the investor" and hence helping the investor balance risks.

Most fintechs specialize in one market segment, with the main advantage of new technologies and data use being lower transaction costs and more convenient processes [20]. However, fintechs can create value in all fields of the financial sector, using different business models and in both the business-to-business (B2B) and business-to-consumer (B2C) markets. The most common models are:

- Payment business models

- Wealth management business models

- Crowdfunding business models

- Lending business models

- Capital market business models

Hence, the business itself is comparable to traditional banking but faster, safer, and at a lower cost [2]. Within this context, there are different approaches to define the structure and characteristics of fintechs. Zavolokina, Dolata, and Schwabe [21] found that fintechs create value not only for banks but in all fields of the financial sector, with the main conditions for fintechs being that technology, organization, and cash flow are needed to create new or disrupt existing, products and services. Fintechs combine technological innovations with the financial sector and contribute to the change from a product to service industry in finance, they write.

The financial market is characterized by the costs of risk aversion due to asymmetric information, resulting in the demand for "new products, services and instruments that can better satisfy financial system participants" [17]. Thus, financial innovations should lead to better investor decisions and, hence, greater investment [17]. Using big data and digitized solutions [22], fintechs present several key advantages: reduced costs for both companies and fintechs and the ability to conduct and see all actions in real-time [13]. Financial technologies strive to make financial services more accessible, efficient, and affordable for customers and change the way traditional services are provided. Hence, fintechs represent the digitization of the financial industry [23].

As with other sectors of the digital economy, fintechs often exploit regulatory loopholes or "conduct business as if the rules did not exist and ask for forgiveness" [24]. Nowadays, customers choose the best service from a variety of companies, and traditional financial institutions increase their investments in external financial start-ups to stay competitive-meaning a noticeable migration from traditional financial services to fintech services. Collaboration between fintechs and established players can take different forms (e.g., partnering, outsourcing, or investment as a venture capitalist).

Fintechs significantly improve service quality by using technologies to build up networks using big data [25], and in this way, real-time data value-creation plays an important role in trust management for potential customers [26]. For traditional financial institutions, fintechs can hence be an excellent source of new innovation in competition. Additionally, fintechs can create technical processes for banks to improve their data security and privacy, meaning banks can use fintechs as an alternative to adopting their own processes according to new regulatory requirements, and start-ups can create new services to meet the demand for risk reduction, privacy, and data security [26].

Goldstein, Jiang, and Karolyi [27] underscore the changing pace of new technologies and suggest that start-ups collaborate with established information technology (IT) companies to introduce new 
products and services. The greatest advantage of these new businesses, especially in the digital economy, is the ability to save costs and hence enhance efficiency [28]. Networks, which are provided by platforms, create new methods to add information and reduce asymmetries, which improves trust. Since there is no clear definition for the term "fintech," Figure 1 provides an overview of the most important characteristics identified.

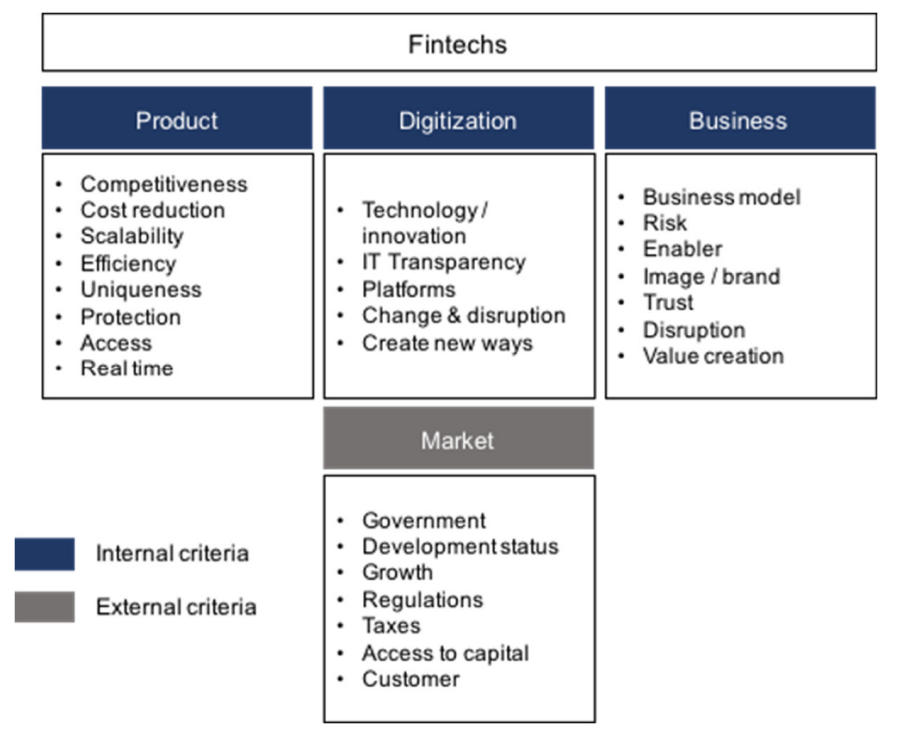

Figure 1. Characteristics of fintechs (own representation based on prior literature).

\subsection{Investor Decision-Making}

A broad range of literature is available on decision-making criteria for funding new start-ups. To create a suitable framework, we have collected all criteria from the literature and then assigned each to a category based on earlier research (e.g., [11,29-33]) or on the context in which the influencing factor is mentioned within the respective paper. Since the business is mainly affected by both organizational factors and the company's environment [3], each criterion adheres to either an internal or an external effect or characteristic of the business [34].

\subsubsection{Internal Decision-Making Criteria}

\section{Management Team/Founder Criteria}

Studies have observed the importance of the founder or management team, finding these individuals to be the most important decision-making criterion for investors [35]. According to the literature, both "soft" and "hard" factors related to the team interest investors, such as the team's experience in terms of the business and industry [11] and the team's personality and characteristics [30,36]. Thus, investors' most important activity prior to funding is to obtain a full picture of the founder and each team member [37]. Additional important criteria for investors are social networks and the reputation of both the business and management team. Networks play an especially important role based on the platform-building for new businesses in the sense that a community of supporters and motivators can be built. This networking idea is affirmed by Gerber and Hui [38], who analyzed decision-making in crowdfunding campaigns (which is also a way for new businesses to become funded); in this regard, founders' social ties are the main influence behind the investment decision [9]. Examining the differences between B2C and B2B businesses, Jovanovic, Brem, and Voigt [39] affirm the positive effect of management team skills for investments only in the B2B market; they found the team does not have a significant effect on investment decisions in $\mathrm{B} 2 \mathrm{C}$ businesses. 


\section{Business and Deal Criteria}

Depending on the stage-and particularly for screening — the business plan can be especially important due to the deep business insights it can provide to potential investors, according to Fried and Hisrich [37]. Additionally, the significant challenges in terms of the business model can be evaluated and weighed by screening the business plan. Due to young business' high degree of flexibility and changes, the business plan can hence help investors evaluate performance estimates and the amount of involvement that would be needed [40]. However, Kirsch et al. [36] determined the business plan has only a ceremonial character and found no evidence that it affects the investment decision; although some content elements do influence investors, the business plan alone is insufficient for communication purposes.

\section{Product Criteria}

Especially in B2B businesses, the product is the key decision criterion [39] —not only the product itself but also its development status, the technology behind it, and protectability, among other factors. In nearly all the papers screened for this study, investors use product-related evaluation as a criterion during their decision-making process. For example, Hoegen et al. [33] underscore the importance of technology in current investment decisions in their study on the differences between traditional financing and crowdfunding. Although their study focuses on crowdfunding rather than general investment, other research demonstrates the trend of technology-driven businesses (e.g., [41]) and that products' technology contributes to the uniqueness of services and hence builds competitive advantages within the market (e.g., $[9,29,41])$.

\section{Financial Criteria}

Most important for investors in terms of financials are potential returns [29,32], with Brem and Wassong [42] and also Gerber and Hui [38] finding this estimated return can even have a greater effect on investors' decisions than the product offering. Alongside this monetary return, companies must consider the exit, which is an investor's opportunity for liquidity [37]. Estimated potential and access are always correlated with the risk of loss, meaning financial motives can lead to syndication on the investor's side due to risk-sharing opportunities [43]. Potential value mainly depends on the general market situation, which operates cyclically; especially in periods of high risk, businesses are more likely to fail but will create comparatively more value when succeeding [44,45]—a financial evaluation validated by a significant body of research on the determinants and key performance indicators surrounding financial decision-making criteria [11].

\subsubsection{External Decision-Making Criteria}

\section{Market Criteria}

In their study on the connection between labour regulations and venture capital, Bozkaya and Kerr [6] found that, in contrast to employment law, labour market regulations and employment protection can have a negative effect on investors' decisions. In this regard, venture capitalists see labour adjustment costs as a significant negative influence on their decision. Bozkaya and Kerr [6] argue that "strict labour regulations hinder venture capital investments, especially in sectors with high labour volatility." In addition to the market and industry conditions $[6,11,29,41,46]$, market criteria also include the investment opportunity's strategic position, according to Muzyka et al. [31]. In this regard, the market's growth potential has been identified as the key factor [35,47], with Tyebjee and Bruno [48] developing a decision-making framework that includes market attractiveness (including the market's size, need, and growth potential, as well as access to the market).

\section{Investor Criteria}

Both hard and soft factors are important to consider in terms of investors themselves. Basic characteristics such as gender, age, and background impact attitudes around risk and, hence, investor behaviour [49]. Additionally, individual experience and preferences affect investment [41,44], and one significant criterion mentioned in the literature is the new business' geographical proximity to the investor. Investors mainly support nearby projects that can then also benefit them [42], 
although Agarwal, Catalini, and Goldfarb [50] found proximity itself is not the key consideration but rather social networks, which are often mainly located in close physical proximity. Additionally, according to Schwienbacher [51], the percentage of investors who prefer investments with regional connections is even higher in Europe (53\%) than in the United States (43\%). A core finding of the current literature is that an investor's focus when evaluating a business depends on the type of investor. Taking financial criteria as an example, the financial model could affect the evaluation [11], but empirical evidence also shows that finances are not considered that important by early-stage investors [47].

In terms of information asymmetries due to the principal-agent problem between investors and entrepreneurs, these asymmetries can be overcome by providing sufficient relevant information for investors to thoroughly evaluate the company [52]. The investor's peer group also offers orientation in terms of which companies they consider trustworthy [53,54]. As described by Pollari and Ruddenklau [1], significant differences exist between the stages and the investment amount-meaning with the amount invested rising, the criteria for the funding decision become more complex. This could also be a reason that more literature exists on venture capital investments compared to other types of investments.

Figure 2 summarizes the funding criteria identified in this section and demonstrates the importance of personal and people-oriented characteristics on both on the investor's and founder's side. Subjective negative feelings cannot be compensated for through other criteria: The investor needs to trust the abilities and experiences of the management team, while the founder needs to be open to external ideas and input $[40,41]$. This personality-oriented approach could part of the reason that no consensus exists on precise investor decision-making criteria [46].

\begin{tabular}{|c|c|c|c|}
\hline & \multicolumn{3}{|c|}{ Investor decision-making } \\
\hline & $\begin{array}{l}\text { Management team } \\
\text { criteria }\end{array}$ & $\begin{array}{l}\text { Business \& deal } \\
\text { criteria }\end{array}$ & $\begin{array}{l}\text { Product / service } \\
\text { criteria }\end{array}$ \\
\hline & \begin{tabular}{|l|} 
- Experiences (individual \\
\& group) \\
- Strategy \& clear plan \\
- Motivition \& vision \\
- Reputation \& \\
references \\
- Personality \& skills \\
(e.g. communication, \\
negotiation, leadership) \\
- Managerial capabilities \\
- Openness \\
- Abilityt to run a \\
business \\
\end{tabular} & $\begin{array}{l}\text { - Company } \\
\text { characteristics (age, } \\
\text { size, attractveness) } \\
\text { Business stage } \\
\text { - Business model \& } \\
\text { orientation } \\
\text { Business plan } \\
\text { - Amount of money } \\
\text { requested }\end{array}$ & $\begin{array}{l}\text { - Characteristics } \\
\text { - Identification } \\
\text {-Differentiation } \\
\text { - Adoption \& distribution } \\
\text { - Status } \\
\text { - Protectability } \\
\text { - Uniqueness } \\
\text { - Technology } \\
\text { - Understandable } \\
\text { business model } \\
\text { - Contribute to } \\
\text { competive advantage }\end{array}$ \\
\hline & Financial criteria & Market criteria & Investor criteria \\
\hline $\begin{array}{l}\text { Internal criteria } \\
\text { External criteria }\end{array}$ & $\begin{array}{l}\text { - Risk simulation \& } \\
\text { attitude } \\
\text { - (Expected) returns } \\
\text { - Cash-outpotential } \\
\text { - Growht potential } \\
\text { - Return on investment } \\
\text { - Time to breakeven \& } \\
\text { payback }\end{array}$ & $\begin{array}{l}\text {-Potential \& growth } \\
\text {-Attractiveness \& } \\
\text { opportunities } \\
\text { - Threat resistance } \\
\text { - Competitive situation } \\
\text { - Available customer } \\
\text {-Characteristics \& } \\
\text { situation } \\
\text { - Entry barriers } \\
\text { - State of VCs }\end{array}$ & $\begin{array}{l}\text { - Type } \\
\text { - General background, } \\
\text { experience \& age } \\
\text { - Emotional, intrinsic } \\
\text { factors, social } \\
\text { motivation \& relation } \\
\text { - Peeer investors } \\
\text { - Local reference \& indiviv. } \\
\text { preferences (market) } \\
\text { - Understanding } \\
\text { - Personal network } \\
\text { - Engagement \& } \\
\text { contribution }\end{array}$ \\
\hline
\end{tabular}

Figure 2. Investor decision-making criteria for start-up funding (own representation based on prior literature).

\section{Materials and Methods}

Following the approach of Brem and Wassong [42], this research uses a literature review and expert interviews. All relevant criteria in terms of investor decision-making and defining fintechs were collected in the literature review, which was used to create a guide for the interviews. 


\subsection{Data Collection}

\subsubsection{Interviews}

Conducting interviews has been a widespread method in research to analyze venture capital decision-making criteria (e.g., [29,47]). This study involved conducting 12 interviews with advisors, founders, and investors in the field of fintechs based on an interview guide. All but two interviews were conducted by telephone, and the interviews were generally standardized but flexible in terms of additional questions and focus-setting. Following Bell, Bryman, and Harley [55], the interview guide covers a broad range of questions organized into three sections, starting with the most general questions, leading to the topic-related specific questions as the main part.

An important reason to use the semi-structured interview approach is because, in structured interviews, questions need to be asked at the same point in each interview [55]; thus, to avoid the question order bias, questions need to be asked twice to maintain the original order and ensure interviews are comparable. For semi-structured interviews, the interview guide can be used as a checklist to ensure all required information has been obtained [56]. The interviews in this study were designed as a combination of expert interview and semi-structured interview, consisting of open questions based on the theoretical background [56]. During a semi-structured interview, the interviewer can change or adjust the questions during the conversation, and it is possible to add or skip questions or change their order, following the interviewee's response. Hence, the results include much of the interviewee's subjective experience [57].

\subsubsection{Sample Selection}

Expert selection criteria were based on Meuser and Nagel's [58] approach. The main characteristic of an expert is specialized knowledge in the relevant research field, which is not accessible to everyone [58]. Although one's position is not the only source of knowledge, privileged access to information in fintechs is based on experience, meaning expert criteria for this study could include their being responsible for the drafting, implementation, or control of a solution to a problem in line with Meuser and Nagel's criteria [58]. Table 1 summarizes information on the interview sample and the interviewees.

Table 1. Interview sample ( $\mathrm{F}=$ female; $\mathrm{M}=$ male).

\begin{tabular}{|c|c|c|c|c|c|c|}
\hline $\begin{array}{c}\# \\
\text { Gender }\end{array}$ & $\begin{array}{c}\text { Date } \\
\text { (dd/mm) } \\
2019\end{array}$ & $\begin{array}{l}\text { Current } \\
\text { Position }\end{array}$ & $\begin{array}{l}\text { Background/ } \\
\text { Experience }\end{array}$ & Location & $\begin{array}{l}\text { Interview Length } \\
\quad \text { (in mins) }\end{array}$ & Medium \\
\hline $\begin{array}{c}1 \\
M\end{array}$ & $26 / 06$ & Fintech Advisor & $\begin{array}{l}\text { Board Member, Mentor, } \\
\text { Conference Host }\end{array}$ & Germany/Singapore & $38: 13$ & Phone \\
\hline $\begin{array}{c}2 \\
\end{array}$ & $05 / 07$ & Member of Advisory Board & $\begin{array}{l}\text { Board Member, Speaker, } \\
\text { Co-Founder, CEO, Advisor }\end{array}$ & Germany & $47: 43$ & Phone \\
\hline $\begin{array}{c}3 \\
\mathrm{M} \\
\end{array}$ & $10 / 07$ & Fintech Co-Founder, CEO & $\begin{array}{l}\text { Consultant, Financial Analyst, } \\
\text { Advisor }\end{array}$ & Switzerland & $\mathrm{n} / \mathrm{a}$ & Written \\
\hline $\begin{array}{c}5 \\
M\end{array}$ & $16 / 07$ & Fintech Advisor, Consultant & $\begin{array}{l}\text { Consultant, Strategic Advisor, } \\
\text { Co-Founder }\end{array}$ & Germany & 29:35 & Phone \\
\hline $\begin{array}{l}6 \\
\mathrm{M}\end{array}$ & $19 / 07$ & Fintech CRO & $\begin{array}{l}\text { Head of Risk and Other Positions } \\
\text { in Banks }\end{array}$ & Germany & $28: 35$ & In-person \\
\hline $\begin{array}{c}7 \\
\mathrm{M}\end{array}$ & $21 / 08$ & $\begin{array}{l}\text { Fintech Co-Founder, President, } \\
\text { CFO }\end{array}$ & Board Member, CFO, Consultant & United States & 23:51 & Phone \\
\hline $\begin{array}{l}10 \\
\mathrm{M}\end{array}$ & $25 / 09$ & Board Member, Investor & $\begin{array}{c}\text { Investor, Board Professional, } \\
\text { Business Angel }\end{array}$ & Finland & $31: 18$ & Phone \\
\hline $\begin{array}{l}11 \\
\mathrm{M}\end{array}$ & $25 / 09$ & Venture Capitalist, Entrepreneur & $\begin{array}{l}\text { Founder, Board Member, Advisor, } \\
\text { Mentor }\end{array}$ & United Kingdom & $31: 34$ & Phone \& Written \\
\hline $\begin{array}{l}12 \\
\mathrm{M}\end{array}$ & $18 / 10$ & $\begin{array}{l}\text { Manager-Fintech, Innovation, } \\
\text { Digital Transformation }\end{array}$ & $\begin{array}{l}\text { Different Positions in Marketing } \\
\text { and E-Business }\end{array}$ & Germany & $51: 35$ & Phone \\
\hline
\end{tabular}

Note: ${ }^{1}$ : During Interview 9, two interviewees with very similar positions answered the questions. As their answers were congruent and only enhanced each other, the interview was handled and evaluated as one interviewee. 


\subsection{Data Evaluation}

In accordance with Gläser and Laudel [59], all interviews were recorded and transcribed. Verbal statements were the main focus of transcription, and non-verbal expressions were only transcribed if they changed the interviewee's meaning. In preparation for analysis, all interviews were anonymized [59].

Qualitative content analysis of the interviews followed the approach of Mayring and Fenzl [12] and involved statement categorization as the most important analytical instrument. Top-level categories were broken into additional subcategories [12], allowing for large amounts of data to be analyzed while maintaining consideration of individual pieces of text. The results were analyzed and interpreted [60] following an inductive approach, with the interview statements summarized to find categories that could be assigned to the information prior derived from theory [12]. Qualitative content analysis is a rule-based method of evaluation [12], and we followed the analytical steps defined by Mayring [61]; each interview corresponded to one evaluation unit, with the level of abstraction for building the categories in Table 2 directed intuitively toward—but always oriented on-the categories derived from the theoretical background [60].

Table 2. Category system.

\begin{tabular}{ccc}
\hline Type of Category & Name of Category & Description \\
\hline Top Category & Internal & All criteria related to the company itself \\
\hline Main Category & Management Team/Founder & $\begin{array}{c}\text { Criteria related to the characteristics and experiences of the management (team)/founder, } \\
\text { both in terms of the company/business and the operating market }\end{array}$ \\
\hline Main Category & Business & Criteria describing the business in terms of key facts and general orientation \\
\hline Main Category & Product/Service & $\begin{array}{c}\text { Criteria related to the product and/or service offered by the company (including, for } \\
\text { example, distribution channels, marketing activities, and product differentiation) }\end{array}$ \\
\hline Main Category & Technology & $\begin{array}{c}\text { Criteria describing the new business innovations and advantages resulting from new } \\
\text { disruptive approaches and development (focusing on technologies related to the financial } \\
\text { industry and products across financial areas) }\end{array}$ \\
\hline Main Category & Financials & $\begin{array}{c}\text { Criteria defining the financial situation and the outlook of the business and its products, } \\
\text { including financial risks }\end{array}$ \\
\hline Top Category & External & Criteria determining the business externally related to stakeholders or conditions \\
\hline Main Category & Economy & $\begin{array}{c}\text { Criteria defining the market in which the company is operating, including economic } \\
\text { developments and conditions }\end{array}$ \\
\hline Main Category & Investor & $\begin{array}{c}\text { Criteria describing the investor, his/her character, and his/her business-related background } \\
\text { and experiences, which affect his/her decisions; the degree of involvement is also covered }\end{array}$ \\
\hline
\end{tabular}

To ensure validity and repeatability, four interviews were coded by a second person (unfamiliar with the topic) to test the logic of coding. The second individual's coding was fundamentally identical to the study coder's (one of the author's) coding, and thus, the remaining interviews were evaluated by only one person. Nevertheless, a second intrapersonal coding took place for all interviews [60]. Based on the results of the 11 prior interviews, the authors returned only to Interviewee 12 to achieve clarification on some statements.

\section{Results}

As Table 3 illustrates, the interviews indicate that investment decisions mainly depend on the team of founders, the criteria describing the business, the product or service offered, the technology, the financial criteria, the economic determinants, and the investors. 
Table 3. Results from advisor's and startup's point of view.

\begin{tabular}{|c|c|c|c|c|c|c|c|}
\hline & Economy & Investor & Management Team/Founder & Product/Service & Financials & Technology & Business \\
\hline \multirow{14}{*}{ Advisors } & Regulation \& politics $(I 1,15,18,19)$ & Background (I8) & Amount of information (I1) & Idea (I1) & $\begin{array}{l}\text { Earnings (I1), in the long } \\
\text { run (I2) }\end{array}$ & User experience (15) & $\begin{array}{l}\text { Business plan evaluated } \\
\text { carefully (I9) }\end{array}$ \\
\hline & Government to push change (I1) & Bad experience $\mathrm{w} /$ trad. banks (I2) & Ability to attract investors (I2) & $\begin{array}{l}\text { Current \& past } \\
\text { developments (I11) }\end{array}$ & $\begin{array}{l}\text { Profit (I2) \& rate of } \\
\text { return (I11) }\end{array}$ & New data usage (I10) & Business model $(\mathrm{I} 1, \mathrm{I} 10)$ \\
\hline & Benefits for customers $(12,15,19)$ & Connection (I10, I11) & $\begin{array}{l}\text { Ability to demonstrate growth (I11), } \\
\text { sales (I2) }\end{array}$ & $\begin{array}{l}\text { Attractiveness (I2) \& } \\
\text { customer centricity (I1) }\end{array}$ & Create value (I8) & Differences b/w B2B \& B2C (I10) & $\begin{array}{l}\text { Flexibility (19), innovation \& } \\
\text { agility (I5) }\end{array}$ \\
\hline & Customer's risk aversion (I11) & Contribution (I10) & $\begin{array}{l}\text { Technical knowledge (19), know-how \& } \\
\text { drive (I1) }\end{array}$ & $\begin{array}{l}\text { Price included in } \\
\text { process (I8) }\end{array}$ & Cash flows (I10) & $\begin{array}{l}\text { Disruption \& extension to new } \\
\text { industries (I9) }\end{array}$ & Less complex (15) \\
\hline & $\begin{array}{l}\text { Data security no } \\
\text { disadvantage (19) }\end{array}$ & Friends \& family unusual (I5) & Ambition (I11) \& independence (I1) & Niche (19) & Forecast (15) & [Internal (I5)] efficiency (I10) & $\begin{array}{l}\text { Development capacity \& } \\
\text { speed (19) }\end{array}$ \\
\hline & Data protection (I10) & Interests (I8) & $\begin{array}{l}\text { Vision \& clear strategy (I9), clarity/idea } \\
\text { (I8) }\end{array}$ & $\begin{array}{l}\text { Marketing (II) \& make } \\
\text { customers willing to } \\
\text { pay (I8) }\end{array}$ & $\begin{array}{l}\text { Key performance } \\
\text { indicators (I11) }\end{array}$ & $\begin{array}{l}\text { Innovation (15, I9) \& Innovation } \\
\text { power (I10) }\end{array}$ & $\begin{array}{l}\text { Speed in business } \\
\text { development }(\mathrm{II}, \mathrm{I}, \mathrm{I} \text {, }\end{array}$ \\
\hline & Instability (I11) & Involvement (I1), at board level (15) & Connected (I8), to market (I8) & Prototype $(15,19)$ & Margins (I11) & $\begin{array}{l}\text { Internet-based (I11) \& mobile } \\
\text { services (II, I9) }\end{array}$ & Customer relationship (19) \\
\hline & Mass audience (I11) & $\begin{array}{l}\text { Involvement (board \& operation; } \\
\text { network \& experience) (I10) }\end{array}$ & $\begin{array}{l}\text { Experience }(15,18, \mathrm{I11}) \& \text { market } \\
\text { know-how }(19)\end{array}$ & $\begin{array}{l}\text { Product demo (I5) \& } \\
\text { development (I1) }\end{array}$ & $\begin{array}{l}\text { Sales (I1) \& revenue (I1, I5, } \\
\text { I9, I11) }\end{array}$ & $\begin{array}{l}\text { Financial Inclusion (I1) \& beyond } \\
\text { banking (I9) }\end{array}$ & $\begin{array}{l}\text { Targets \& traction (I8), B2B } \\
\text { (I5) \& B2C (I9) }\end{array}$ \\
\hline & Competition (I1, I5), location (I5) & Location (I1), depending on fund (I5) & Heterogeneity (19) \& gender (I1) & & Mass/scalability (I2) & Data protection as enabler (I5) & Global approach (I5) \\
\hline & $\begin{array}{l}\text { International development (I5), } \\
\text { Language (I11) }\end{array}$ & $\begin{array}{l}\text { Other investors \& herd instinct (I11), } \\
\text { herd instinct (II, I9) }\end{array}$ & Independence (I1) & $\begin{array}{l}\text { Solution (I1, 19) of } \\
\text { meaningful problem (I11) }\end{array}$ & $\begin{array}{l}\text { Scalability (II, I5, I9), by } \\
\text { going international (I11) }\end{array}$ & $\begin{array}{l}\text { Platform (I1, I5), connection through } \\
\text { platform (I11) }\end{array}$ & Capital requirements (15) \\
\hline & $\begin{array}{l}\text { Market entry barriers (I5), market } \\
\text { access (CLV \& CAC) (I8, I11) }\end{array}$ & Personality (II) \& strategy (19) & Personality (I10) \& self-confidence (I1) & $\begin{array}{l}\text { Niche (I9), unique selling } \\
\text { point \& value add (I2) }\end{array}$ & Burn-rate (I11) & $\begin{array}{l}\text { Technical possibility to realize } \\
\text { things (I9) }\end{array}$ & $\begin{array}{l}\text { Entity (I5), corporate culture } \\
\text { or governance (I2) }\end{array}$ \\
\hline & $\begin{array}{l}\text { Market conditions (I5), size (I8) } \\
\text { and market growth (I1) }\end{array}$ & Risk attitude $(11,15,19,110)$ & Less influence of character (I8) & $\begin{array}{l}\text { Viable commercial model \& } \\
\text { MVP (I11) }\end{array}$ & & API (I8) \& automation (I5) & Customer relationship (19) \\
\hline & $\begin{array}{l}\text { Market changes (I2, I5), lead to } \\
\text { uncertainty (I1) }\end{array}$ & Stage $(12,15) \&$ type $(11,12,111)$ & $\begin{array}{l}\text { Language (19) \& similarities in culture } \\
\text { (110) }\end{array}$ & $\begin{array}{l}\text { Rewriting \& retooling of } \\
\text { existing services (I11) }\end{array}$ & & $\begin{array}{l}\text { New methods (15), offerings in a new } \\
\text { way }(12,110)\end{array}$ & \\
\hline & Market reputation (I5) & & $\begin{array}{l}\text { Personal contact to team (I5) \& team } \\
\text { qualities (I1) } \\
\text { Trustworthiness (I5) \& reputation (I11) } \\
\text { Understanding (I11) \& timing (I10) }\end{array}$ & & & & \\
\hline \multirow{8}{*}{ Startups } & $\begin{array}{l}\text { Customers (I6) \& available } \\
\text { market (I7) }\end{array}$ & $\begin{array}{l}\text { Type (I6), e.g., sweats for equity } \\
\text { venture capitalists (I7) }\end{array}$ & Skills (I4) \& experience (I3, I6, I7) & Idea (I4) & Cost Advantage (I4) & $\begin{array}{l}\text { Innovative solutions \& customer } \\
\text { enablement (I6) }\end{array}$ & $\begin{array}{l}\text { Business model \& business } \\
\text { plan (I7) }\end{array}$ \\
\hline & Data security (I6) & $\begin{array}{l}\text { Business Angel (Type) (I4) \& BAs } \\
\text { directly involved (I3) / ongoing } \\
\text { interaction (I3) }\end{array}$ & Impression (I4) & $\begin{array}{l}\text { Designed for } \\
\text { enhancements (I4) }\end{array}$ & Efficiency $(13,14)$ & $\begin{array}{l}\text { Progressive strategy (I4), efficiency } \\
\text { (I3), easier \& faster (I6) }\end{array}$ & Business stage (17) \\
\hline & $\begin{array}{l}\text { Data protection leads to value } \\
\text { add (I4) }\end{array}$ & $\begin{array}{l}\text { No (I7) / Careful with family \& } \\
\text { friends (I4) }\end{array}$ & Independence (I4) & Marketing mix (I6) & Return (I7) & Software (I4) \& IT (I6) & $\begin{array}{l}\text { Business information (plan } \\
\& \text { personal) (I3) }\end{array}$ \\
\hline & Regulations (I4) as a risk (I7) & $\begin{array}{l}\text { Location (I7), [close (I4)] relationship } \\
\& \text { involvement (I7) }\end{array}$ & Network (I3) & Simple (I6) / MVP (I7) & Risk \& valuation (I4) & Mobile \& digital applications (I6) & Create brand (I7) \\
\hline & Market changes (I6) & $\begin{array}{l}\text { Herd instinct influence } \\
\text { trustworthiness (17) }\end{array}$ & Passion \& [clear (I4)] vision (I3) & $\begin{array}{l}\text { Utilize technology to } \\
\text { service (I7) }\end{array}$ & Scalability (I3) & $\begin{array}{l}\text { Platforms (I7) as ecosystem (14), Data } \\
\text { (I4) ecosystems (I7) }\end{array}$ & Quick decisions \& speed (I6) \\
\hline & $\begin{array}{l}\text { International developments \& } \\
\text { risks (I7) }\end{array}$ & Newsletter for friends \& family (I3) & $\begin{array}{l}\text { Personality, e.g., during direct pitching } \\
\text { (I3) }\end{array}$ & Distribution model (I4) & & $\begin{array}{l}\text { Connection through website as } \\
\text { platform (I3) }\end{array}$ & $\begin{array}{l}\text { Speed in business } \\
\text { growth (I7) }\end{array}$ \\
\hline & & $\begin{array}{l}\text { Stage: strong long-term relationship, } \\
\text { later more related to numbers (I7) }\end{array}$ & Age (I7) \& CV (I7) & & & $\begin{array}{l}\text { Transparency (I3, I4) \& regulations as } \\
\text { benefit (I7) }\end{array}$ & B2C (I6) \\
\hline & & Strategy about time to fund (I4) & & & & $\begin{array}{l}\text { Open access (I3) \& service } \\
\text { integration (I6) }\end{array}$ & \\
\hline
\end{tabular}




\subsection{Internal Criteria}

\section{Management Team/Founder}

The management team/founder's importance changes over time. The management team plays a key role in particular at the beginning of the funding process. As Interviewee 10 noted, "In the first phase, it is the case that the funds do not have such great interest. First of all, there is no financial data. Often there is no product and the turnover is zero. It's only about investment to develop the technology. So, there is actually only the people behind the company." The management team forms the basis to successfully promote a technological product that is solving a customer problem, with management's experience, age, and CV having been mentioned by interviewees as especially important; these factors are mostly correlated and interdependent, and the management team should have high heterogeneity in terms of know-how to cover diverse business fields.

\section{Business}

For fintechs, rapidity is important both in terms of market entry and in terms of finding collaboration partners or investors. In this regard, it can be essential to be the first player and grow quickly. Due to specialization and collaboration with banks, most fintechs are active in the B2B market environment, although $\mathrm{B} 2 \mathrm{C}$ fintechs can be more successful from a revenue perspective (but require greater up-front investment). Since the capital requirements for a new financial start-up are quite high in general, most fintechs offer their services to banks and businesses instead of directly to consumers. Compared to established players, fintechs are more flexible in terms of adapting to changing market conditions. For investors, the business stage determines their decision as to investors' investment focus.

\section{Product/Service}

Fintechs' products and services should generally solve a customer problem, and most products serve a niche market. The problem of product imitation is not currently visible in the market for several reasons: The high complexity of IT makes it difficult for competitors to copy, and only companies with a unique selling point will survive-meaning patents can be seen as an advantage but are not a key criterion for potential investors or partners. Alongside the product itself, distribution and market positioning must be clear.

All interviewees said the product is essential to prospective investors' decision and is seen as the first touchpoint with the potential start-up partner. Interviewee 9 said, "The solution will definitely appeal to me; that's why I'm talking to this fintech or they're talking to us." In the beginning, it is not only about paper-based pitching but also presenting a prototype, which does not need to work perfectly but must highlight the product's basic functions. To ensure customers' willingness to pay, the product needs to be easily understandable. Hence, from the investor's point of view, most lucrative services adapt existing ones in a new and easier way.

\section{Technology}

Fintechs' technological advantage over traditional financial institutions is their key driver of success and competitive advantage. Fintechs' technologies should have a value-add for the customer ("customer-centricity"), and mobile and data-based services can enhance efficiency. Another characteristic of fintechs is their ability to connect people or services through platforms: "[W]hen you create a meaningful connection between, like, two endpoints interacting through your platform, then you can charge sometimes exorbitant fees and benefit from this connection" (Interviewee 11). Web- and data-based platforms are important for creating new services. Hence, products or services can be connected with other services from different industries, which leads to value creation for customers. Since the technology should be usable, it needs to be easy, fast, and understandable. Therefore, technological complexity needs to be reduced.

\section{Financials}

A key requirement of fintechs' new technologies is the scalability of products and services. Scalability is based on having a notable number of lucrative customers who use the technology and generate sales and revenue. Investors use different key performance indicators to determine scalability, which requires companies to first generate data or sell products. Hence, financial criteria can only be 
used at a later stage of the investment process, and a financial plan (e.g., a business plan) can provide a first impression, albeit one that should be used carefully.

Financial success is generally achieved by a well-established company that also delivers on the other criteria. Interviewee 10 notes, "[Doing] the right thing at the right time and well packaged, then you can achieve cash flow pretty quickly." Heavy competition also means businesses "that work globally will always triumph over regional suppliers" (Interviewee 5), and so the global approach is a major driver of success.

\subsection{External Criteria}

\section{Economy}

The majority of interviewees mentioned the competitive context shaping the fintech market, including both new start-ups and traditional banks. Diverse international developments in fintech markets are the result of banking-market infrastructure differing between developed and developing countries. Comparing Europe and Asia (and specifically from developing countries in Asia) illustrates this contrast: Europe fintechs are mostly an addition or collaborative partner for banks, while Asian financial start-ups build a new base for banking because "beyond Germany . . 2.5 billion people have no access at all to money and an account" (Interviewee 2). Hence, the missing banking infrastructure pushes fintech development forward and speeds it up.

This process is also subject to regulatory requirements, which differ significantly among countries. Whereas potential investors and partners in Germany prefer start-ups that are already familiar with regulatory requirements, for example, this familiarity plays a subordinate role in some markets (e.g., the United States). Almost all European interviewees mentioned the current regulatory situation as a strong influence on investment. For fintechs, regulations and other barriers to market entry can have an enormous effect on their success and attractiveness to potential investors. Interviewee 12, for example, highlighted the importance of regulatory status and mentioned German regulations to be a potential threat to fintech development. Furthermore, the most important element for investors is an available market in terms of scalable customers. Interviewee 2 recommended, "Don't look at the relationship with your investor; look at the relationship with your customer." There are international differences as well. For example, German customers have a high level of risk aversion and so data-security rules play an enormous role in this market; Interviewee 5 believes that "it is especially a German problem that data is always dramatized in such a way."

\section{Investor}

The study sample included a diverse range of investors, and the differences in their responses indicate how different types of investors value decision-making criteria differently. Regarding geographical proximity, most interviewees said that it is not about the location itself but rather the investor's network in a specific area and the cultural and language similarities. Interviewee 10, in particular, discussed the importance of the investor's influence and involvement, as well as the investor's desire to contribute to the company and bring in his network and contacts to manage the fintech successfully in his role as a business angel (an individual who is usually involved in the company early and want to contribute to and have a close relationship with the company). Interviewee 4 emphasized investors' influence and said from his experience as a business angel, early-stage investors help companies establish contacts and both advise and participate in decisions on strategic development.

A balance must be struck between involvement and independence. Most investors also want to see who is already involved and what other connections exist, and several interviewees mentioned decisions based on this "herd instinct." The most important result in terms of the investor is that involvement depends mainly on the stage at which they enter the business and the type of investor. Especially at the beginning, investors want to bring their connections and experience into the company; at a later stage, though, the management team should be able to act independently and investors only advise. In fintech, banks are both providers of money and collaborators. Bank groups in particular 
partner with fintechs to ensure their technological development and innovativeness, collaborating to build new, more disruptive business models and enhance their portfolio through new services (e.g., beyond banking products).

Table 3 demonstrates that investors have a much broader picture of the entire decision-making process and of influences in the fintech market than founders do. Many similarities exist between funding decisions in financial start-ups and those in other businesses, and the investment decision is determined by both hard and soft factors. Figure 3 depicts the founding cycle and highlights that the most critical criteria depend on the respective investor type.

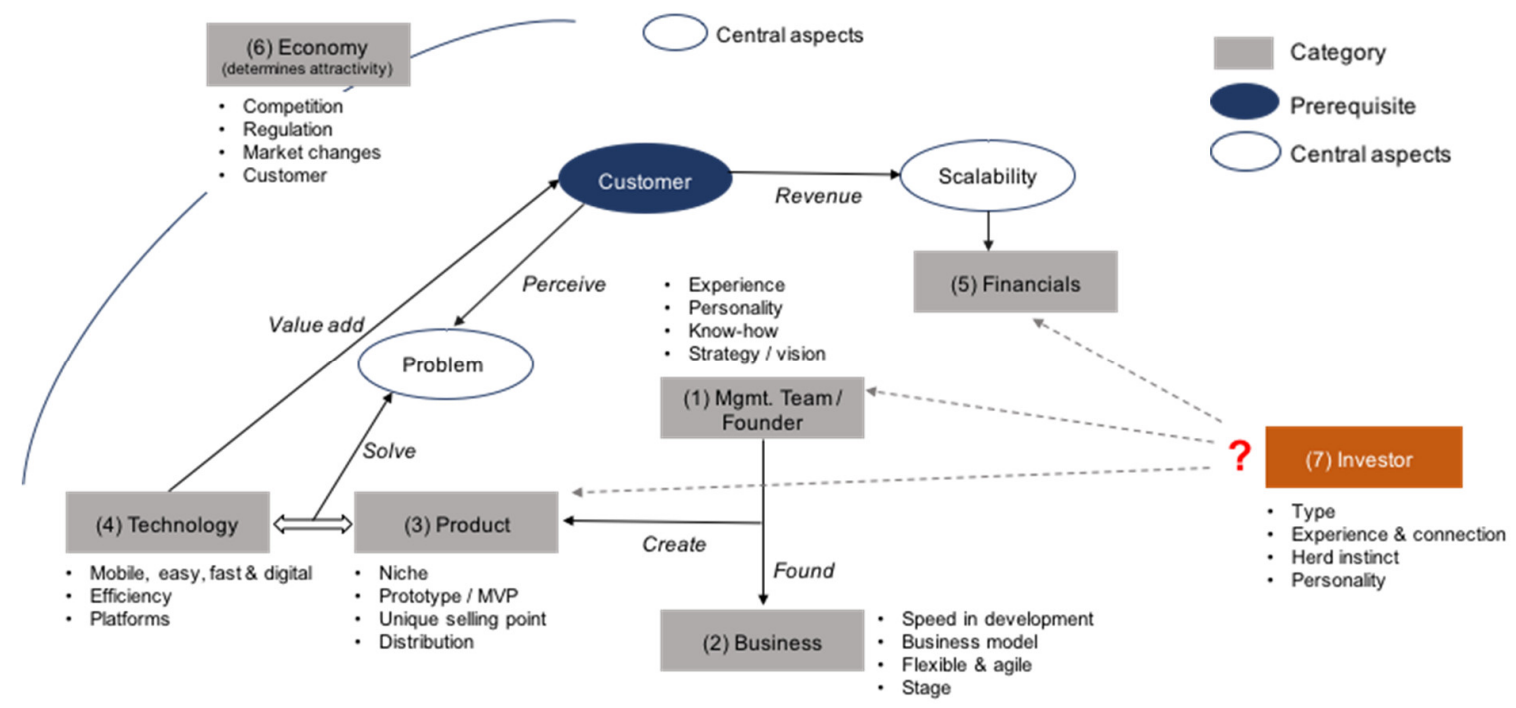

Figure 3. Grouped interview results on decision-making (own representation).

\section{Discussion, Implications, and Limitations}

This study aimed to combine decision-making and trends related to new fintech start-ups to determine which components attract investors most when they are deciding whether to invest in a fintech company. A key result is that this question has different answers depending on the funding stage and investor focus. Both the literature and the empirical results demonstrate the importance of the management team for early-stage investors, which is true for most businesses in the digital economy. The management team must have a clear vision and a strategy for running the business successfully to earn investor trust; in particular, founders with broad subject experience and relevant market experience can gain investors. During pitch sessions, team members must be able to convince potential investors of their ability to distribute the product and find further investors. Nevertheless, depending on the business' stage and position, the management team could be replaced as a leading criterion by other criteria, such as generated revenue. Business angels' interest in founders' personality in particular results from their close connection and collaboration during the business' initial stages, with gender also to surface as thereby impacting investors' decisions.

Regarding investors' involvement in the company, no clear consensus emerges. For some interviewees, direct involvement and responsibility (e.g., on the board) are of the utmost importance; others, however, feel the management team should be able to run the business successfully on their own. Therefore, this study cannot fully affirm the results of earlier research $[62,63]$. Although regular meetings and discussions should take place, later-stage investors do not want to proactively influence management decisions. The empirical results also do not see geographical proximity as an important factor in the decision to invest [42], although investment mostly does have a local character that is not due to the location but rather to cultural consistencies and an available network. In general, investors are open to investing in companies located far from their original market if all other determinants meet their expectations. Whereas for the founders funding through friends and family is mentioned as a 
useful source of capital at the beginning, investors see this kind of funding critical, providing no clear indication of its general relevance in funding decisions [64].

Depending on the business' maturity, the type of investor fundamentally determines the investment decision. This result is found both in the literature $[42,65]$ and this study's empirical findings. Trust between founder and investor is key to a successful partnership; this is in line with Harrison and Mason [62] and with Moritz et al. [53], who found that an investor's decision is subject to emotional and intrinsic motivation. Another phenomenon affirmed by this study is that investors follow investment trends.

Additionally, in line with the findings of Angerer et al. [32], this study found that financial data is one of the investors' main motivations. Along with the few key performance indicators described in available research, this study's interviewees underscored the importance of efficiency to generate the expected revenues, as financial performance measures are scarce for innovation activities [66]. Interviewees also said scalability is of the utmost importance in generating revenues. The literature also mentions scalability and growth potential $[35,47]$, and thus, fintech start-ups should strive to set up their business with scalable products, as scalability is one of the key characteristics of digital economy business models $[67,68]$. Based on customer availability, investors focus on scalable products for which the customer is willing to pay. Therefore, potential investors are especially interested in seeing prototypes-a requirement that is not yet included in the literature. Modern investors are no longer only focused on potential numbers but also on existing prototypes and processes, which fits Kirsch et al.'s [36] finding that fintechs' business plans have only a ceremonial effect. Nevertheless, this study cannot fully resolve uncertainty about the business plan's role since the plan has been mentioned by interviewees as an essential source of information but a clear focus also exists on a product prototype and method of using technology to service. Despite this technological part, the protection of this service, as analyzed by Maxwell et al. [11], was not confirmed during the evaluation of this study's empirical results. Although it can be seen as positive, investors do not appear to care much about this criterion.

In terms of the banking sector, this study's results enhance the current state of the literature in highlighting that fintechs serve a niche market and, unlike traditional banks, focus on a special product or service. Additionally, prior literature has focused on general digital aspects of technology in the financial industry and changes to existing services by using new technologies (e.g., [14]). This study deepened insights in this field and highlights that from a technological perspective, fintechs should enhance the efficiency of services and reduce costs to attract investors. Technological implementation, related digital economy business models, and integrating services from different areas allow businesses to provide offerings beyond the traditional banking boundaries. Both the literature and empirical evidence indicate that based on digitization and the implementation of platforms, fintechs can offer new ways of doing business in the banking market.

Market-related research exists on how economic conditions affect investors. In banking, companies' current situation is shaped by uncertainty and instability, resulting in an increasing amount of regulations in this sector. Regulatory requirements are seen as having a significant impact on both the business environment and technological opportunities, while companies in the digital economy often exploit regulatory loopholes [13,24]. Related to market potential [11], investors want to see how customers can be accessed and do not focus on technological protection from imitation in their discussions. Nevertheless, the study analysis reveals that protection by building market entry barriers [41] is important.

In general, the study findings related to fintech investors' decision-making are in line with findings from prior literature in the field of business angel and venture capital investment, showing few differences between fintechs and other digital economy business models or more traditional markets. However, including banks as investors in this discussion offers a different perspective: Since banks are not only investors in fintechs but also often stakeholders, their position has changed compared to that with other start-up investments. Little research focuses on banks' business funding compared 
to traditional debt investments even though banks are a major source of funding for start-ups and remain the largest investors in business funding [69]. In general, banks can boost the start-up market by providing easy access to money in both developing and developed countries [70]. According to this study and earlier research [2], regulation is a driver of technological development-especially in the banking environment-and can be converted easily by fintechs in the digital economy. In this regard, a major advantage of young businesses is their more rapid and agile development capacity, which makes them an intriguing partner for traditional banks. Hence, this study demonstrates, banks and fintechs' current interdependence is due to valuable support in implementing new regulatory requirements. Therefore, unlike with other start-ups in the digital economy, banks are not solely investors but also partners (or competitors). Whereas in other markets, start-ups ask banks purely for funding, fintechs can be seen as essential for banks to increase their innovativeness and to help to meet and implement regulatory requirements.

\subsection{Implications}

\section{Implications for Research}

This study examines current research in the field and enhances it in terms of decision-making criteria for funding fintechs. By providing deep insight into investor behaviour, this study highlights that investors' decision-making criteria mainly depend on the type of investor and that the business stage plays an important role in the decision to invest due to changing objectives. Criteria for investment are interrelated and should not be considered separately. Additionally, in the context of the significant changes currently occurring in the banking market, the study results underscore the importance of technological development amidst market uncertainty. Although the body of literature on decision-making is already well-established, this study found additional criteria for the financial industry and found the context surrounding fintechs to differ from the available literature in terms of confirmed factors. The broad range of interviewees also provides insight from different perspectives to gain a clear and complete view on the topic, and the study notes the lack of research on bank investors and includes the changing position of traditional banks within the current market and the digital economy.

\section{Implications for Practice}

Companies should provide omnichannel offerings and create new solutions for customers combining services (beyond banking). As with many markets in which new entrants from the digital economy operate, specializing in single services could lead to future consolidation in the financial market. Fintechs and banks would both benefit from collaboration founded on trust, and government entities and companies should push digitization and technologies to remain competitive, including internationally. Fintechs must maintain their ability to implement new processes in an agile, rapid manner to remain an interesting partner for banks and receive investor attention, as "the sharing economy will become more fully embedded in financial services" [71]. Additionally, founders must consider a range of aspects when starting their business, including market determinants. Somewhat different from other endeavours in the digital economy, this study found, fintech businesses should only be started by experienced founders with a clear vision of how to begin and operate. Even though early investors are willing to support and invest in fintechs, as with other digital economy business models that can quickly become scalable, founders should be primarily able to run the business by themselves.

\subsection{Limitations and Directions for Further Research}

In terms of limitations, the characterization of venture capitalists depends on their business style, specialization, and firm size [8]; the age and experience of the venture capital firm itself and its geographical proximity to the fintech affect the method of investment significantly [51]. Hence, our experts represent only a selected sample. Additionally, this study's theoretical background is based on a broad range of literature from different areas of study and time periods. Technology firms in general, and fintechs and other digital economy business models in particular, operate in 
a rapidly changing environment, meaning prior literature might not be up to date in terms of the latest developments.

It is also important to note that, following Swider, Barrick, Harris, and Stoverink [72], the interview's first few minutes are the most important in developing the interviewee's impression of the interview. Hence, the interviewer-interviewee relationship is largely created at the beginning of the interview and results are subject to these initial impressions. Additionally, although the study avoided this whenever possible, any interviewer intervention could influence the interviewee's response [55].

Despite extensive research on decision-making, the connection to certain industries and businesses is still underrepresented in the literature. Currently, research exists on B2B and B2C businesses in general (e.g., [42]) but without a focus on specific sectors. Decision-making in specific industries would be an interesting avenue for future research specifically in terms of stakeholders' changing positions and sector-specific singularities in the decision-making process. Especially in the continuously changing market environment (due to, for example, digitalization and technology), industry-related research can foster development in diverse fields to better understand approaches to create new offerings [28]. With respect to investment decisions, researchers and companies alike would thus better understand the prerequisites to successfully attracting investors.

Author Contributions: Conceptualization, K.H. and P.M.B.; methodology, K.H. and P.M.B.; data collection and analysis, K.H.; writing—original draft preparation, K.H.; writing—review and editing, P.M.B. All authors have read and agreed to the published version of the manuscript.

Funding: This research received no external funding.

Acknowledgments: P.M.B. gratefully acknowledges support by the FAU Emerging Talents Initiative (grant 2019/2_WiSo_02).

Conflicts of Interest: The authors declare no conflict of interest.

\section{References}

1. Pollari, I.; Ruddenklau, A. The Pulse of Fintech-Biannual Global Analysis of Investment in Fintech. KPMG International Cooperative (Ed.). 2019. Available online: https://assets.kpmg/content/dam/kpmg/xx/pdf/2019/ 02/the-pulse-of-fintech-2018.pdf (accessed on 27 February 2020).

2. Lee, I.; Shin, Y. Fintech: Ecosystem, business models, investment decisions, and challenges. Bus. Horiz. 2018, 61, 35-46. [CrossRef]

3. Moro Visconti, R. Fintech Valuation. Available online: https://ssrn.com/abstract=3533869 (accessed on 7 February 2020).

4. Benjaafar, S.; Kong, G.; Li, X.; Courcoubetis, C. Peer-to-peer product sharing: Implications for ownership, usage, and social welfare in the sharing economy. Manag. Sci. 2019, 65, 477-493. [CrossRef]

5. Breidbach, C.F.; Ranjan, S. How do Fintech Service Platforms Facilitate Value Co-Creation? An Analysis of Twitter Data. In Proceedings of the Thirty Eighth International Conference on Information Systems, Seoul, Korea, 10-13 December 2017; pp. 1-14.

6. Bozkaya, A.; Kerr, W.R. Labor Regulations and European Venture. J. Econ. Manag. Strategy 2014, 23, 776-810. [CrossRef]

7. Arner, D.W.; Barberis, J.; Buckley, R.P. The Evolution of Fintech: A New Post-Crisis Pradigm? Georget. J. Int. Law 2016, 47, 1271-1319. [CrossRef]

8. Norton, E.; Tenenbaum, B.H. The effects of venture capitalists' characteristics on the structure of the venture capital deal. J. Small Bus. Manag. 1993, 31, 32-41.

9. Shane, S.; Cable, D. Network Ties, Reputation, and the Financing of New Ventures. Manag. Sci. 2002, 48, 364-382. [CrossRef]

10. Maxwell, A.L.; Jeffrey, S.A.; Lévesque, M. Business angel early stage decision making. J. Bus. Ventur. 2009, 26, 212-225. [CrossRef]

11. Henninger, P.; Brem, A.; Giones, F.; Bican, P.M.; Wimschneider, C. Effectuation vs. Causation: Can established firms use Start-Up Decision-Making Principles to stay innovative? Int. J. Innov. Manag. 2020, 24, 2050002. [CrossRef] 
12. Mayring, P.; Fenzl, T. Qualitative Inhaltsanalyse. In Handbuch Methoden der Empirischen Sozialforschung; Baur, N., Blasius, J., Eds.; Springer Fachmedien Wiesbaden: Wiesbaden, Germany, 2014; pp. 543-556.

13. Arner, D.W.; Barberis, J.; Buckley, R.P. FinTech, RegTech, and the Reconceptualization of Financial Regulation. Northwestern J. Int. Law Bus. 2017, 37, 371-414.

14. Lacasse, R.M.; Lambert, B.A.; Couture, C.; Roy, N.; Sylvain, J.; Nadeau, F. A Digital Tsunami: FinTech and Crowdfunding. In Proceedings of the International Scientific Conference on Digital Intelligence, Quebec City, QC, Canada, 4-6 April 2016.

15. Haddad, C.; Hornuf, L. The emergence of the global fintech market: Economic and technological determinants. Small Bus. Econ. 2019, 53, 81-105. [CrossRef]

16. Bican, P.M.; Guderian, C.C.; Ringbeck, A. Managing Knowledge in Open Innovation Processes: An Intellectual Property Perspective. J. Knowl. Manag. 2017, 21, 1384-1405. [CrossRef]

17. Frame, W.S.; White, L.J. Empirical Studies of Financial Innovation: Lots of Talk, Little Action? J. Econ. Lit. 2004, 42, 116-144. [CrossRef]

18. Ozili, P.K. Impact of digital finance on financial inclusion and stability. Borsa Istanb. Rev. 2018, 18, 329-340. [CrossRef]

19. Scott, S.V.; Van Reenen, J.; Zachariadis, M. The long-term effect of digital innovation on bank performance: An empirical study of SWIFT adoption in financial services. Res. Policy 2017, 46, 984-1004. [CrossRef]

20. Claessens, S.; Frost, J.; Turner, G.; Zhu, F. Fintech Credit Markets around the World: Size, Drivers and Policy Issues. BIS Q. Rev. 2018, 29-49. Available online: https://papers.ssrn.com/sol3/papers.cfm?abstract_id= 3288096 (accessed on 5 July 2020).

21. Zavolokina, L.; Dolata, M.; Schwabe, G. FinTech Transformation: How IT-Enabled Innovations Shape the Financial Sector. Lect. Notes Bus. Inf. Process. 2017, 276, 75-88.

22. Bican, P.M.; Brem, A. Digital Business Model, Digital Transformation, and Digital Entrepreneurship: Is there a Sustainable Digital? Sustainability 2020, 12, 5239. [CrossRef]

23. Ma, Y.; Liu, D. Introduction to the special issue on Crowdfunding and FinTech. Financ. Innov. 2017, 3, 1-8. [CrossRef]

24. Wall, L.D. Avoiding Regulation: FinTech versus the Sharing Economy. 2016. Available online: https://www.frbatlanta.org/cenfis/publications/notesfromthevault/09-avoiding-regulation-fintech-versusthe-sharing-economy-2016-09-29 (accessed on 5 July 2020).

25. DeStefano, R.; Tao, L.; Gai, K. Improving Data Governance in Large Organizations through Ontology and Linked Data. In Proceedings of the 2016 IEEE 3rd International Conference on Cyber Security and Cloud Computing, Beijing, China, 25-27 June 2016; pp. 279-284.

26. Gai, K.; Qiu, M.; Sun, X. A survey on FinTech. J. Netw. Comput. Appl. 2017, 103, 262-273. [CrossRef]

27. Goldstein, I.; Jiang, W.; Karolyi, G.A. To Fintech and Beyond. Rev. Financ. Stud. 2019, 32, $1647-1661$. [CrossRef]

28. Matzler, K.; Veider, V.; Kathan, W. Adapting to the sharing economy. Mit Sloan Manag. Rev. 2015, 56, 71-77.

29. Macmillan, I.C.; Siegel, R.; Subba Narasimha, P.N. Criteria used by venture capitalists to evaluate new venture proposals. J. Bus. Ventur. 1985, 1, 119-128. [CrossRef]

30. MacMillan, I.C.; Zemann, L.; Subbanarasimha, P.N. Criteria distinguishing successful from unsuccessful ventures in the venture screening process. J. Bus. Ventur. 1987, 2, 123-137. [CrossRef]

31. Muzyka, D.; Birley, S.; Leleux, B. Trade-offs in the investment decisions of European venture capitalists. J. Bus. Ventur. 1996, 11, 273-287. [CrossRef]

32. Angerer, M.; Brem, A.; Kraus, P.; Peter, A. Start-up Funding via Equity Crowdfunding in Germany-A Qualitative Analysis of Success Factors. J. Entrep. Financ. 2017, 19, 1-34.

33. Hoegen, A.; Steininger, D.M.; Veit, D. How do investors decide? An interdisciplinary review of decision-making in crowdfunding. Electron. Mark. 2018, 28, 339-365. [CrossRef]

34. Kloviené, L. Institutional Factors as Criteria for Business Environment Identification. Ecoman 2012, 17, 1245-1251. [CrossRef]

35. Roure, J.B.; Maidique, M.A. Linking prefunding factors and high-technology venture success: An exploratory study. J. Bus. Ventur. 1986, 1, 295-306. [CrossRef]

36. Kirsch, D.; Goldfarb, B.; Gera, A. Form of Substance: The Role of Business Plans in Venture Capital Decision Making. Strateg. Manag. J. 2009, 30, 487-515. [CrossRef] 
37. Fried, V.; Hisrich, R. Toward a Model of Venture Capital Investment Decision Making. Financ. Manag. 1994, 23, 28-37. [CrossRef]

38. Gerber, E.; Hui, J. Crowdfunding: Motivations and Deterrents for Participation. ACM Trans. Comput. Hum. Interact. 2013, 20, 1-34. [CrossRef]

39. Jovanovic, T.; Brem, A.; Voigt, K.-I. Who invests why? An analysis of investment decisions in b2b or b2c equity crowdfunding projects. Int. J. Entrep. Small Bus. 2019, 37, 71-86. [CrossRef]

40. Gerasymenko, V.; De Clercq, D.; Sapienza, H.J. Changing the business model: Effects of venture capital firms and outside CEOs on portfolio company performance. Strateg. Entrep. J. 2015, 9, 79-98. [CrossRef]

41. Landström, H. Informal investors as entrepreneurs. Technovation 1998, 18, 321-333. [CrossRef]

42. Brem, A.; Wassong, N. Wer investiert warum? Eine Analyse von Investmententscheidungen bei Crowdfunding-Projekten. Zfke-Z. Für Kmu Entrep. 2014, 62, 31-55. [CrossRef]

43. Lockett, A.; Wright, M. The syndication of venture capital investments. OMEGA-Int. J. Manag. Sci. 2001, 29, 375-390. [CrossRef]

44. Nanda, R.; Rhodes-Kropf, M. Investment Cycles and Startup Innovation. J. Financ. Econ. 2012, 110, 403-418. [CrossRef]

45. Riar, F.J.; Bican, P.M.; Fischer, J. It wasn't me: Entrepreneurial Failure Attribution and Learning from Failure. Int. J. Entrep. Ventur. 2020, in press.

46. Hudson, E.; Evans, M. A Review of Research into Venture Capitalists' Decision Making: Implications for Entrepreneurs, Venture Capitalists and Researchers. J. Econ. Soc. Policy 2005, 10, 1-18.

47. Silva, J. Venture capitalists' decision-making in small equity markets: A case study using participant observation. Ventur. Cap. 2004, 6, 125-145. [CrossRef]

48. Tyebjee, T.; Bruno, A. A Model of Venture Capital Activity. Manag. Sci. 1984, 30, 1051-1066. [CrossRef]

49. Dohmen, T.; Falk, A.; Huffman, D.; Sunde, U.; Schupp, J.; Wagner, G. Individual risk attitudes: Measurement, determinantes, and behavioral consequences. J. Eur. Econ. Assoc. 2011, 9, 522-550. [CrossRef]

50. Agarwal, A.; Catalini, C.; Goldfarb, A. The Geography of Crowdfunding. NET Inst. Work. Pap. 2011. [CrossRef]

51. Schwienbacher, A. Venture capital investment practices in Europe and the United States. Financ. Mark. Portf. Manag. 2008, 22, 195-217. [CrossRef]

52. Zacharakis, A.; Meyer, G. The potential of acturial decision models: Can they improve the venture capital investment decision. J. Bus. Ventur. 2000, 15, 323-346. [CrossRef]

53. Moritz, A.; Block, J.; Lutz, E. Investor communication in equity-based crowdfunding: A qualitativ-empirical study. Qual. Res. Financ. Mark. 2015, 7, 309-342. [CrossRef]

54. Dibben, M.; Harrison, R.; Mason, C. The role of trust in the informal investors' investment decision: An exploratory analysis. In Management Buy-Outs and Venture Capital into the Millennium; Wright, M., Robbie, K., Eds.; Edward Elgar: Cheltenham, UK, 1999; pp. 115-138.

55. Bell, E.; Bryman, A.; Harley, B. Business Research Methods, 5th ed.; Oxford University Press: Oxford, UK, 2019.

56. Mey, G.; Mruck, K. Interviews. In Handbuch Qualitative Forschung in der Psychologie; Mey, G., Mruck, K., Eds.; VS Verlag für Sozialwissenschaften: Wiesbaden, Germany, 2010; pp. 423-435.

57. Gray, D.E. Doing Research in the Real World, 4th ed.; SAGE: Thousand Oaks, CA, USA, 2018.

58. Meuser, M.; Nagel, U. Das Experteninterview-Konzeptionelle Grundlagen und methodische Anlage. In Methoden der Vergleichenden Politik- und Sozialwissenschaft: Neue Entwicklungen und Anwendungen; Pickel, S., Pickel, G., Lauth, H.-J., Jahn, D., Eds.; VS Verlag für Sozialwissenschaften: Wiesbaden, Germany, 2009; pp. 465-479.

59. Gläser, J.; Laudel, G. Experteninterviews und Qualitative Inhaltsanalyse als Instrumente Rekonstruierender Untersuchungen, 4th ed.; VS Verlag: Wiesbaden, Germany, 2010.

60. Früh, W. Inhaltsanalyse: Theorie und Praxis, 8th ed.; UTB: Konstanz, München, 2015; Volume 2501.

61. Mayring, P. Qualitative Inhaltsanalyse. In Handbuch Qualitative Forschung in der Psychologie; Mey, G., Mruck, K., Eds.; VS Verlag für Sozialwissenschaften: Wiesbaden, Germany, 2010; pp. 601-613.

62. Harrison, R.T.; Mason, C.M. Venture capital market complementarities: The links between business angels and venture capital funds in the United Kingdom. Ventur. Cap. Int. J. Entrep. Financ. 2000, 2, 223-242. [CrossRef]

63. Bachher, J.; Guild, P. Financing early stage technology based companies: Investment criteria used by investors. Front. Entrep. Res. 1996, 21, 363-376. 
64. Avdeitchikova, S.; Landstrom, H.; Månsson, N. What do we mean when we talk about business angels? Some reflections on definitions and sampling. Ventur. Cap. Int. J. Entrep. Financ. 2008, 10, 371-394. [CrossRef]

65. Bertoni, F.; Colombo, M.G.; Grilli, L. Venture capital financing and the growth of high-tech start-ups: Disentangling treatment from selection effects. Res. Policy 2011, 40, 1028-1043. [CrossRef]

66. Bican, P.M.; Brem, A. Managing innovation performance: Results from an industry-spanning explorative study on R\&D key measures. Creat. Innov. Manag. J. 2020, 29, 268-291.

67. Acquier, A.; Carbone, V.; Massé, D. How to create value (s) in the sharing economy: Business models, scalability, and sustainability. Technol. Innov. Manag. Rev. 2019, 9, 5-24. [CrossRef]

68. Täuscher, K.; Kietzmann, J. Learning from failures in the sharing economy. Sci. Technol. 2017, 67, $2047-2059$.

69. Deutsche Bundesbank: PSD2. 2019. Available online: https://www.bundesbank.de//de/aufgaben/unbarerzahlungsverkehr/psd2/psd2-775434 (accessed on 27 November 2019).

70. Naudé, W.; Gries, T.; Wood, E.; Meintjies, A. Regional determinants of entrepreneurial start-ups in a developing country. Entrep. Reg. Dev. 2008, 20, 111-124. [CrossRef]

71. Gomber, P.; Kauffman, R.J.; Parker, C.; Weber, B.W. On the fintech revolution: Interpreting the forces of innovation, disruption, and transformation in financial services. J. Manag. Inf. Syst. 2018, 35, 220-265. [CrossRef]

72. Swider, B.W.; Barrick, M.R.; Harris, T.B.; Stovernik, A.C. Managing and Creating an Image in the Interview: The Role of Interviewees initial Impressions. J. Appl. Psychol. 2011, 96, 1275-1288. [CrossRef]

(C) 2020 by the authors. Licensee MDPI, Basel, Switzerland. This article is an open access article distributed under the terms and conditions of the Creative Commons Attribution (CC BY) license (http://creativecommons.org/licenses/by/4.0/). 